\title{
Hemolytic, anticancer and antigiardial activity of Palythoa caribaeorum venom
}

\author{
Fernando Lazcano-Pérez ${ }^{1}$, Ariana Zavala-Moreno', Yadira Rufino-González², Martha Ponce-Macotela², \\ Alejandro García-Arredondo ${ }^{3}$, Miguel Cuevas-Cruz' , Saúl Gómez-Manzo ${ }^{4}$, Jaime Marcial-Quino ${ }^{5}$, \\ Barbarín Arreguín-Lozano and Roberto Arreguín-Espinosa ${ }^{1 *}$
}

\begin{abstract}
Background: Cnidarian venoms and extracts have shown a broad variety of biological activities including cytotoxic, antibacterial and antitumoral effects. Most of these studied extracts were obtained from sea anemones or jellyfish. The present study aimed to determine the toxic activity and assess the antitumor and antiparasitic potential of Palythoa caribaeorum venom by evaluating its in vitro toxicity on several models including human tumor cell lines and against the parasite Giardia intestinalis.

Methods: The presence of cytolysins and vasoconstrictor activity of $P$. caribaeorum venom were determined by hemolysis, PLA 2 and isolated rat aortic ring assays, respectively. The cytotoxic effect was tested on HCT-15 (human colorectal adenocarcinoma), MCF-7 (human mammary adenocarcinoma), K562 (human chronic myelogenous leukemia), U251 (human glyoblastoma), PC-3 (human prostatic adenocarcinoma) and SKLU-1 (human lung adenocarcinoma). An in vivo toxicity assay was performed with crickets and the antiparasitic assay was performed against $\mathrm{G}$. intestinalis at $24 \mathrm{~h}$ of incubation.

Results: P. caribaeorum venom produced hemolytic and PLA $A_{2}$ activity and showed specific cytotoxicity against U251 and SKLU-1 cell lines, with approximately 50\% growing inhibition. The venom was toxic to insects and showed activity against $G$. intestinalis in a dose-dependent manner by possibly altering its membrane osmotic equilibrium.
\end{abstract}

Conclusion: These results suggest that $P$. caribaeorum venom contains compounds with potential therapeutic value against microorganisms and cancer.

Keywords: Cnidarian, Palythoa caribaeorum, Cytotoxin, Antitumoral effect, Giardiasis

\section{Background}

The phylum Cnidaria comprises approximately 11,000 species classified into seven classes (Anthozoa, Scyphozoa, Cubozoa, Staurozoa, Polypodiozoa, Myxozoa and Hydrozoa) [1]. All of them are considered to be toxic [2]. Moreover, some of them have been reported to be capable of causing severe intoxication by stinging with their specialized organelles called nematocysts [3]. Extracts of cnidarian tissues have been found to contain a complex mixture of low molecular weight compounds,

\footnotetext{
* Correspondence: arrespin@unam.mx

1Departamento de Química de Biomacromoléculas, Instituto de Química, Universidad Nacional Autónoma de México, Av. Universidad 3000, Ciudad Universitaria, C.P. 04510. Apdo, Postal 70250 Mexico City, Mexico

Full list of author information is available at the end of the article
}

peptides and proteins that together cause the paralysis and envenomation of their prey or predator $[4,5]$.

Venoms isolated from almost all classes of cnidarians have been found to be cytotoxic in several cellular or animal models [6]. Among the best known cytotoxic venoms are the Portuguese man-of-war hydrozoan Physalia physalis, the box jellyfish Chironex fleckeri, the jellyfish Pelagia noctiluca, the fire coral Millepora complanata and many sea anemones extracts [7-14]. Due to the wide range of biological activities of these venoms, many substances isolated from them, especially those derived from sea anemones, have served as useful molecular models and probes in biomedical research [15]. However, the antimicrobial activity of such extracts has been little explored. A few reports can be found in the 
literature about the antiparasitic and antibacterial properties of some cnidarians and even an antimicrobial peptide isolated from Aurelia aurita has been sequenced $[16,17]$.

Zoanthids (order Zoantharia, class Anthozoa) are organisms commonly found in shallow zones of coral reefs. This group of cnidarians has not been extensively studied as other cnidarians such as sea anemones or jellyfish. Some biochemical and toxicological research on zoanthids have proved that they possess compounds with biological activity. For instance, the existence of palytoxin, one of the most potent marine toxins known to man and first isolated on a zoanthid of the gender Palythoa, later discovered to be synthesized by dinoflagellates $[18,19]$. Besides palytoxin, not many studies on the biological activity of zoanthid venoms or toxins have been characterized to date. An extract of their soft tissues was tested for antibacterial activity and it was found that it inhibits Escherichia coli and Staphylococcus aureus in 97.7 and 100\%, respectively [20]. More recently, $P$. caribaeorum extracts were found to have antioxidant effects and cytotoxic activities [21].

According to Suput [15], an assessment of the pharmacological actions of cnidarian venoms and crude extracts is still missing due to the fact that several types of toxins coexist in the same venom. Therefore, it would be important to know not only the effect of a particular toxin but the total effect of the whole venom in vitro and in vivo. Hence, the aim of the present work is to characterize some pharmacological aspects of Palythoa caribaeorum venom in terms of hemolytic, antiparasitic and anticancer activities in order to use this organism as a source of new compounds with potential use as candidate drugs.

\section{Methods}

\section{Laboratory animals}

All experiments were performed in accordance with the Official Standard NOM-062-ZOO-1999 for the production, care, and use of laboratory animals. The care and use of the animals was approved by the Bioethics Committee of the School of Medicine, UAQ.

\section{Venom extraction}

P. caribaeorum organisms were collected by free diving in La Gallega coral reef in Veracruz, México. The crude extract was obtained according to the method described elsewhere [22]. Briefly, the organisms were carefully separated from the rocks using a chisel and a hammer. In the laboratory, the material was cleaned from remaining rock and soaked in water to eliminate superficial mucus. In order to extract nematocyst venom, the organisms were carefully squeezed in deionized water to expose hidden polyp tentacles and mechanically discharged.
The solution was then centrifuged twice at 70,000 g for 15 min at $4{ }^{\circ} \mathrm{C}$, lyophilized, and stored at $-70{ }^{\circ} \mathrm{C}$ until use.

\section{Hemolytic activity assay}

The hemolytic assay was performed as described by Rottini et al. [23] with some modifications. Human erythrocyte suspension was prepared from fresh blood from a healthy donor. Blood was collected in a flask with Alsever's solution buffer ( $\mathrm{pH}$ 6.4) containing dextrose (0. $116 \mathrm{M}), \mathrm{NaCl}(0.071 \mathrm{M})$, sodium citrate $(0.027 \mathrm{M})$ and citric acid $(0.002 \mathrm{M})$. The suspension was centrifuged at $2500 \mathrm{rpm}$ for $5 \mathrm{~min}$ at $4{ }^{\circ} \mathrm{C}$ and the supernatant was decanted. This step was repeated three times and the final pellet was resuspended in Alsever's buffer. Erythrocytes were incubated at two temperatures $37^{\circ} \mathrm{C}$ and $60^{\circ}$ $\mathrm{C}$ for $30 \mathrm{~min}$ in the presence of different venom concentrations ranging from 1 to $10 \mathrm{mg} / \mathrm{mL}$. Immediately after incubation, the samples were centrifuged at $2500 \mathrm{rpm}$ for $5 \mathrm{~min}$ at $4{ }^{\circ} \mathrm{C}$ and the optical density of supernatant was measured using a spectrophotometer at $415 \mathrm{~nm}$. The results were normalized to $100 \%$ hemolysis by diluting the erythrocytes in deionized water and adjusting the absorbance $\mathrm{A}_{415}$ to 0.9 when total lysis occurred.

\section{Phospholipase $A_{2}$ assay}

Phospholipase $\mathrm{A}_{2}\left(\mathrm{PLA}_{2}\right)$ activity of the aqueous extract was determined using a secretory $\mathrm{PLA}_{2}$ colorimetric assay kit (Cayman Chemical, USA). This assay uses the 1,2-dithio analogue of diheptanoyl phosphatidylcholine as substrate. Free thiols generated upon hydrolysis of the thioester bond at the sn- 2 position by $\mathrm{PLA}_{2}$ were detected using DTNB [5,5'-dithio-bis-(2-nitrobenzoic acid) ]. Color changes were monitored by a Benchmark Plus microplate spectrophotometer at $414 \mathrm{~nm}$, sampling every minute for $10 \mathrm{~min}$. As reference for $\mathrm{PLA}_{2}$ activity, $10 \mu \mathrm{L}(10 \mu \mathrm{g})$ of bee venom PLA $_{2}$ was used as control. $\mathrm{PLA}_{2}$ activity was expressed in $\mu \mathrm{mol}$ of hydrolyzed phosphatidylcholine per minute per mg of protein $(n=3)$.

\section{Isolated rat aortic ring assay}

Male Wistar rats (275-325 g) were anesthetized with chloroform, sacrificed by decapitation and the descending thoracic aorta was removed and placed in ice-cold, oxygenated Krebs-Henseleit solution $(126.8 \mathrm{mM} \mathrm{NaCl}$, $5.9 \mathrm{mM} \mathrm{KCl}, 2.5 \mathrm{mM} \mathrm{CaCl} 2,1.2 \mathrm{mM} \mathrm{MgSO} 4,1.2 \mathrm{mM}$ $\mathrm{KH} 2 \mathrm{PO} 4,30 \mathrm{mM} \mathrm{NaHCO}$, and $5 \mathrm{mM}$ D-glucose, $\mathrm{pH} 7$. 4) and immediately flushed with Krebs-Henseleit solution to prevent intravascular clot formation. The aorta was dissected free of adipose and connective tissue and cut into 4 to 5 - $\mathrm{mm}$ rings. The aortic rings were mounted between stainless steel hooks and suspended in 7-mL of water-jacketed organ baths containing oxygenated (95\% $\mathrm{O}_{2}$ and $5 \% \mathrm{CO}_{2}$ ) Krebs-Henseleit solution at $37{ }^{\circ} \mathrm{C}$. The 
tissues were allowed to equilibrate for $60 \mathrm{~min}$ under a resting tension of $1.5 \mathrm{~g}$. During this period, the bathing medium was exchanged every $15 \mathrm{~min}$. After final adjustment of the passive resting tension to $1.5 \mathrm{~g}$, aortic segments were contracted with $100 \mathrm{mM} \mathrm{KCl}$.

Once a stable contractile tone was reached, the bathing medium was replaced to restore a resting tension of 1.5 g. After that, the tissues were contracted with $1 \mu \mathrm{M} \mathrm{L}$-phenylephrine, the force of contraction was recorded, and this contraction was set as $100 \%$. The bathing medium was replaced again to restore a resting tension, and then the extract or the fractions were added to the organ bath. The isometric tension was measured by a Grass FT03 force-displacement transducer attached to a Grass 7D polygraph. The responses were expressed as a percentage of the initial contraction achieved with phenylephrine. The half-maximal effective concentration $\left(\mathrm{EC}_{50}\right)$ and the maximum effect $(\mathrm{Emax})$ values were interpolated by fitting log concentration-response curves ( $n=3 /$ curve) using non-linear regression analysis.

\section{Insect toxicity assay}

Insect toxicity of the extract was determined by using undetermined sex crickets (Acheta domestica) weighing between 200 and $250 \mathrm{mg}$ by a method previously described [24]. Briefly, lyophilized extracts were dissolved in insect saline solution $[200 \mathrm{mM} \mathrm{NaCl}, 3.1 \mathrm{mM} \mathrm{KCl}, 5$. $4 \mathrm{mM} \mathrm{CaCl}, 4 \mathrm{mM} \mathrm{MgCl}_{2}, 2 \mathrm{mM} \mathrm{NaHCO} 3,0.1 \mathrm{mM}$ $\mathrm{Na}_{2} \mathrm{HPO}_{4} ; \mathrm{pH}$ 7.2] and administrated by thoracic injection into crickets (five crickets per dose) at several doses $(1,3.2,10,31.6,100$, and $316 \mu \mathrm{g}$ protein $/ \mathrm{mL})$. The injection volume for all crickets, including the controls that received insect saline solution, was $10 \mu \mathrm{L}$. Injections were performed using a $0.3-\mathrm{mL}$ gauge insulin syringe (BD Ultra-Fine, Terumo Medical Corporation, USA). After the injection, crickets were placed in small plastic containers with food and water ad libitum. Mortality was scored at 24 and $48 \mathrm{~h}$ post-injection. The lethal dose 50 $\left(\mathrm{LD}_{50}\right)$ values were interpolated by fitting log doseresponse curves ( $n=3 /$ curve) using non-linear regression analysis.

\section{Cytotoxicity assay}

The cytotoxic extract was screened in vitro against human cancer cell lines: HCT-15 (human colorectal adenocarcinoma), MCF-7 (human mammary adenocarcinoma), K562 (human chronic myeloid leukemia), U251 (human glyoblastoma), PC-3 (human prostatic adenocarcinoma), SKLU-1 (human lung adenocarcinoma) and the normal cell lines MT-2 human lymphocytes and J774 rat macrophages. Cell lines were supplied by the National Cancer Institute (NCI, USA). The human tumor cytotoxicity was also determined by using the protein binding dye sulforhodamine B (SRB) in microculture assay to measure cell growth as described in the protocols established by the NCI [25].

The cell lines were cultured in RPMI-1640 medium supplemented with $10 \%$ fetal bovine serum, $2 \mathrm{mM} \mathrm{L-}$ glutamine, 10,000 units/mL penicillin G, 10,000 $\mu \mathrm{g} / \mathrm{mL}$ streptomycin sulfate and $25 \mu \mathrm{g} / \mathrm{mL}$ amphotericin B (Gibco). The cultures were maintained at $37{ }^{\circ} \mathrm{C}$ in a $5 \%$ $\mathrm{CO}_{2}$ humidified atmosphere. With the exception of $\mathrm{K}$ 562 and MT-2 cell lines, the rest of the adherent cell lines were removed from the tissue culture flask by adding of $1 \mathrm{~mL}$ of $0.05 \%$ trypsin-EDTA (GIBCO-laboratories) and diluted with fresh media. The viability of the cells used in the experiments exceeded $95 \%$ as determined with trypan blue. For the assay, $100 \mu \mathrm{L}$ containing 5000-10,000 cells/ well was seeded in 96-well microtiter plates (Costar) and incubated to allow for cell attachment.

After $24 \mathrm{~h}$ of incubation, $100 \mu \mathrm{L}$ of a solution of the test extract obtained by diluting the stocks was added to each well. The cultures were exposed for $48 \mathrm{~h}$ to the extract at concentrations of $100 \mu \mathrm{g} / \mathrm{mL}$. After the incubation period, cells were fixed to the plastic substratum by the addition of $50 \mu \mathrm{L}$ of cold $50 \%$ aqueous trichloroacetic acid. The plates were incubated at $4{ }^{\circ} \mathrm{C}$ for $1 \mathrm{~h}$, washed with tap $\mathrm{H}_{2} \mathrm{O}$ and air-dried. The trichloroacetic-acid fixed cells were stained by the addition of $0.4 \%$ SRB. Free SRB solution was then removed by washing with $1 \%$ aqueous acetic acid. The plates were then air-dried and the bound dye was solubilized by the addition of $10 \mathrm{mM}$ unbuffered Tris base $(100 \mu \mathrm{L})$. The plates were placed on a shaking platform for $5 \mathrm{~min}$ and the absorption was determined at $515 \mathrm{~nm}$ using an ELISA plate reader (Bio-Tex Instruments).

\section{Antiparasitic assay}

Antiparasitic activity was performed against Giardia intestinalis (WB reference strain, ATCC 30957). Trophozoites were cultured in TYI-S-33 medium in $13 \times$ $100 \mathrm{~mm}$ test tubes. When trophozoites were in monolayer (until logarithmic phase of growing), medium was replaced by phosphate buffer (PBS), $\mathrm{pH} 7.0$, cooled in ice for $15 \mathrm{~min}$ and centrifuged during $5 \mathrm{~min}$ at $3500 \mathrm{rpm}$. PBS was removed and the trophozoites were counted in a Neubauer chamber. Tests were done in Eppendorf tubes with a final volume of $1.5 \mathrm{~mL}$ by using a 50,000 trophozoites/mL of TYI-S-33 medium, and different concentrations $(1,0.5 .0,25,0.125$ and $0.0625 \mathrm{mg} /$ $\mathrm{mL})$ of $P$. caribaeorum extract. Metronidazole $(10 \mu \mathrm{g} /$ $\mathrm{mL}$ ) was used as positive control. Tubes were incubated at $37{ }^{\circ} \mathrm{C}$ for $24 \mathrm{~h}$ following by cooling in ice for $15 \mathrm{~min}$ and centrifuged. The supernatant was discarded and new medium was added for reculture during for $24 \mathrm{~h}$ at $37{ }^{\circ} \mathrm{C}$. Finally, trophozoites were quantified in a Neubauer cell-counter chamber. Percentage of dead 
trophozoites was plotted against log concentration. $\mathrm{IC}_{50}$ and $\mathrm{IC}_{90}$ were calculated by graphic extrapolation with JPM 9.0 software.

\section{Results}

\section{Bioassays}

The extract obtained exhibited concentration-dependent hemolytic activity on human erythrocytes. In addition, the activity was reduced, but not abolished, when the extract was incubated in a water bath at $60{ }^{\circ} \mathrm{C}$ for $10 \mathrm{~min}$ (Fig. 1). It also showed a PLA $\mathrm{P}_{2}$ activity of $0.155 \pm 0$. $009 \mu \mathrm{mol} / \mathrm{min} / \mathrm{mg}$, while $\mathrm{PLA}_{2}$ from bee venom, used as control, displayed an activity of $14.734 \pm 0.624 \mu \mathrm{mol} /$ $\mathrm{min} / \mathrm{mg}$. This enzymatic activity was completely lost when the venom was incubated in boiling water bath for $30 \mathrm{~min}$. The induced vasoconstriction on rat aortic rings showed an $\mathrm{EC}_{50}=4.287 \pm 1.766$ with an $\mathrm{E}_{\max }=108.2 \pm 7$. 167 (Fig. 2).

The insecticidal activity results showed that $P$. caribaeorum venom was lethal to crickets, the determined $\mathrm{LD}_{50}$ values at $24 \mathrm{~h}$ and $48 \mathrm{~h}$ for $P$. caribaeorum venom was $50.92 \pm 10.85$ and $3.78 \pm 0.243 \mu \mathrm{g}$ protein/g respectively (Fig. 3). The venom did not induce immediate paralysis, but at higher concentrations, motility was gradually reduced.

\section{Cytotoxicity assay}

The major inhibitory effect on tumoral cell lines was observed on the glyoblastoma cell line U251 (52.61\%), followed by a $41.5 \%$ inhibition activity of human lung cancer cells SKLU-1. No significant activity was observed on the rest of the tumoral lines tested. The venom also showed a high inhibition on rat macrophages 7774 (53.0\%), but slight activity on human T lymphocytes MT-2 (11.01\%). No activity was observed against the other cell lines.

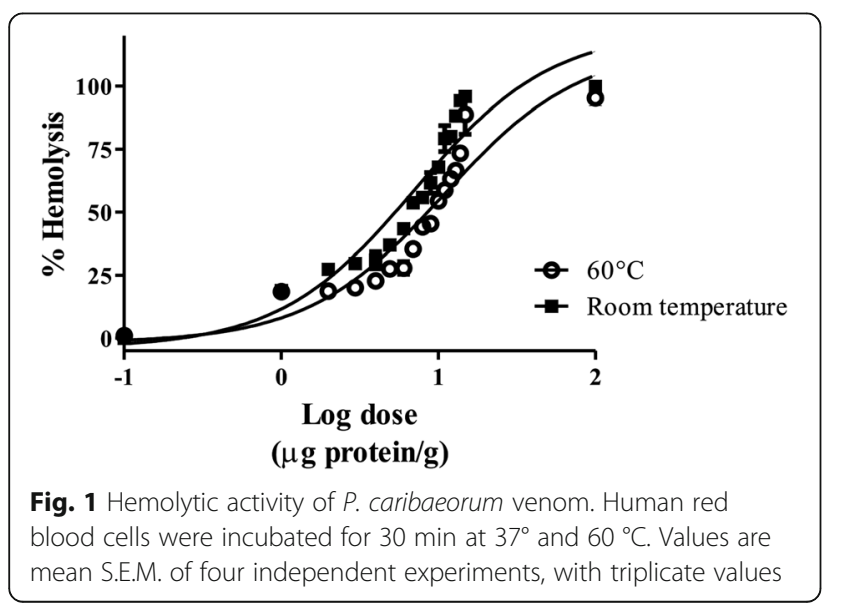

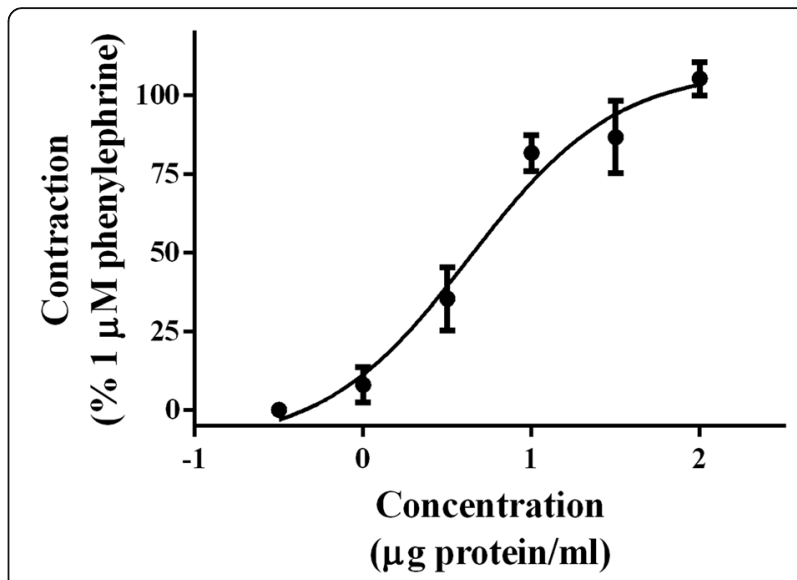

Fig. 2 Concentration-response curve showing the vasoconstrictor effect of $P$. caribaeorum venom on rat isolated aorta. Values are expressed as mean \pm S.E.M. $(n=3)$. Concentration represents protein content in the extracts

\section{Antiparasitic assay}

The antiparasitic tests against $G$. intestinalis showed that the extract contains substances capable of killing the parasite in a dose-dependent manner (Fig. 4). The $\mathrm{IC}_{50}$ and $\mathrm{IC}_{90}$ values were 116 and $603 \mu \mathrm{g} / \mathrm{mL}$, respectively. These values are high compared to that of metronidazole $\left(\mathrm{IC}_{50}=\right.$ $0.55 \mu \mathrm{g} / \mathrm{mL}$ and $\mathrm{IC}_{90}=3.54 \mu \mathrm{g} / \mathrm{mL}$ ), however, this is a whole extract. Trophozoites exposed to $500 \mu \mathrm{g} / \mathrm{mL}$ and $1000 \mu \mathrm{g} / \mathrm{mL}$ of the venom showed an atypical morphology: rounded, increased in volume, presence of large vacuoles and even many of them were lysed (Fig. 5). These characteristics suggest that the active substances affect the membrane by a mechanism that affects the osmotic equilibrium and finally lysing the cell.

\section{Discussion}

Animals that produce venom are known for the adverse effects that they may provoke in humans, such as allergic reactions, dermatitis, hemorrhage, intravascular coagulation, necrosis, respiratory failure, etc. For this

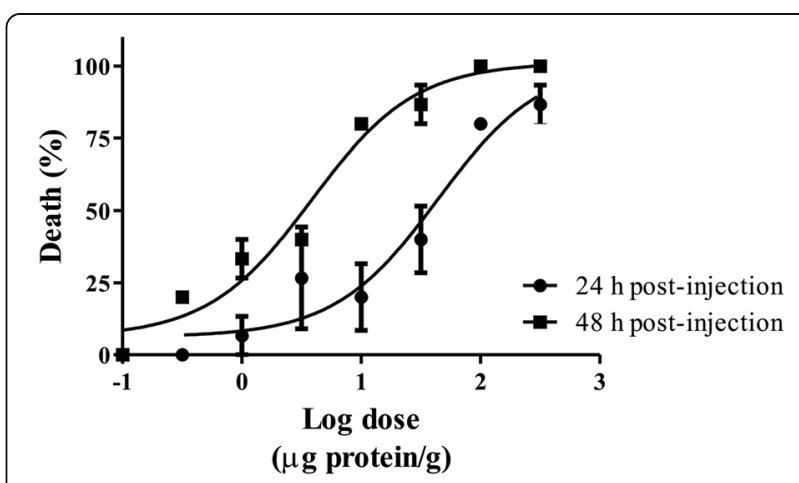

Fig. 3 Toxicity of $P$. caribaeorum venom on crickets (A. domestica) at 24 and $48 \mathrm{~h}$ post-injection 


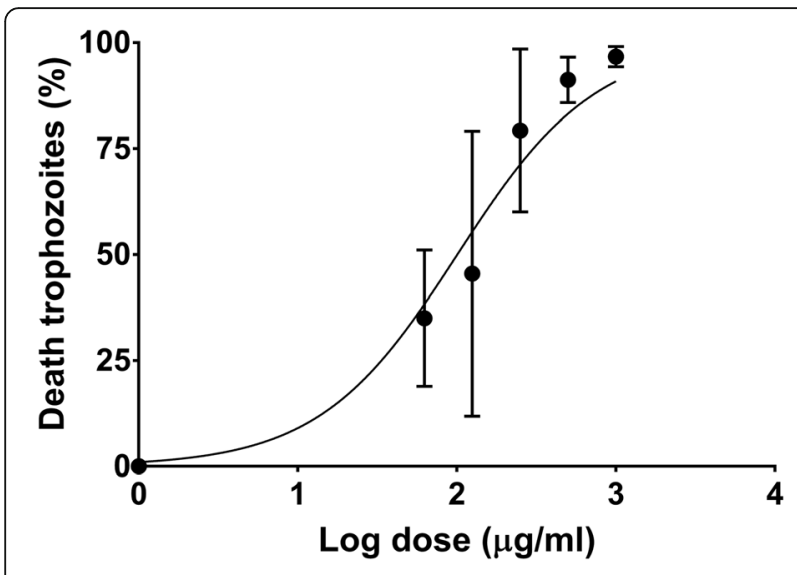

Fig. 4 Antigiardial activity of Palythoa cariboeroum whole extract

reason, they have become a source of substances with distinct pharmacological properties, many of them explored in cancer research. In recent years, cnidarian extracts and venoms, especially those from sea anemones and jellyfishes, have been investigated for their pharmacological properties in order to find new molecules with potential therapeutic activity [6].

Cnidarian cytolysins, besides being important factors for envenomation, have been extensively studied in terms of their mechanisms of action and are being recognized as tools for biotechnological and pharmaceutical applications [26]. The hemolytic properties of extracts from many species of cnidarians have been widely reported [6]. It has been reported that cnidarian cytolysins act in two ways: by forming pores in the membrane (known as actinoporins in sea anemones) or hydrolyzing certain membrane phospholipids (phospholipases). These toxins are used by cnidarians for the capture and digestion of prey.

Palythoa prey comprise fish larvae and planktonic crustaceans, thus, it is likely that its toxins are active against insects. Some sea anemone toxins have been tested on insect voltage-gated sodium channels and specifically one neurotoxin, $\mathrm{CgNa}$ from Condylactis gigantea, strongly inhibits the inactivation of the insect voltage-gated sodium channel $[27,28]$. In a previous study, we found that the extracts of three scleractinian corals induce toxicity on crickets [29]. In the present study, we found that $P$. caribaeorum extract also showed insecticidal activity with gradual paralysis until death with a major potency than that induced by the scleractinian corals. This activity, as with sea anemones, is consistent with the existence of toxins affecting voltage-gated ion channels. The presence of neurotoxic activity in $P$. caribaeorum venom has already been tested on mammalian neurons, but their specificity on these kind of cells over insect channels remains to be determined [30].

In general, local skin reactions and pain are characteristic in cnidarian envenomation. However, some cases result in systemic symptoms such as increased heart rate and cardiovascular collapse [31]. Up to now, the knowledge on cardiovascular toxicity caused by cnidarian venom is limited. Several studies have reported the presence of vasoconstrictor components in diverse cnidarian extracts $[32,33]$. The results of the present study reveal the presence of vasoconstrictor components in the extract of $P$. caribaeorum; however, further studies are necessary to elucidate the chemical characteristics and mechanism of these components.

Since ancient times, animal venoms have been used in traditional medicine to treat several diseases such as cancer. Among these, snake venoms have been the most studied. Several toxins, mainly phospholipases, isolated from snakes have been ascribed as the enzymes responsible for the anticancer effect. In addition, some phospholipases $\mathrm{A}_{2}$ are cytotoxic to tumor cells, but devoid of lethality, hemolytic and anticoagulant activities which may be suitable for pharmaceutical purposes [33].

The cytotoxicity of extracts from many species of sea anemones on several cancer cell lines has been reported $[34,35]$. Our results showed that the extract specifically inhibits approximately $40 \%$ of SKLU-1 human lung adenocarcinoma cells and more than $50 \%$ of U251 human glioblastoma. SKLU-1 cell line was reported to be sensitve to the sea anemone Bunodeopsis globulifera venom when applied along with cisplatin [36]. According to these results, it may be of great interest to study cnidarian venoms in order to discover molecules that in combination with anticancer drugs may allow the reduction of chemotherapy doses [6].
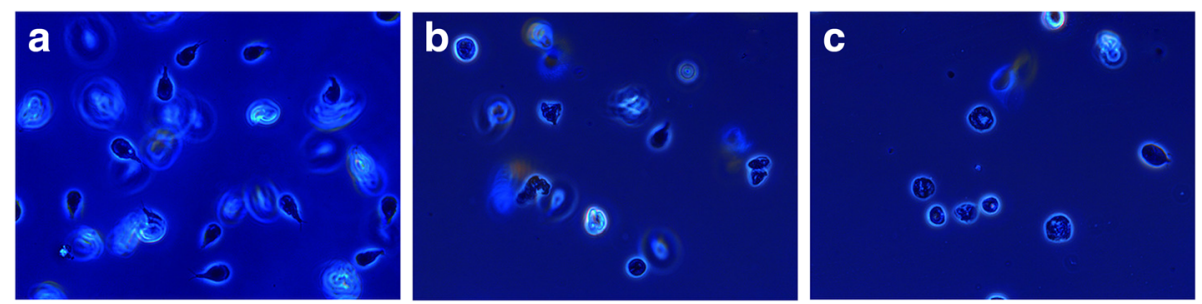

Fig. 5 Acivity of $P$. caribaeorum extract on Giardia intestinalis trophozoites. a Trophozoites without extract, (b) trophozoites exposed to $500 \mu \mathrm{g} /$ $\mathrm{mL}$, (c) Trophozoites with $1000 \mu \mathrm{g} / \mathrm{mL}$ of extract 
One of the major causes of human diarrheal diseases, particularly in children, is giardiasis. There are several substances against the parasite G. intestinalis, but it is believed that their massive use can result in the development of resistance. Metronidazole is the drug of choice against giardiasis, but is not $100 \%$ effective and may produce undesirable side effects such as headaches and metallic taste in the mouth [37]. It has also been shown to be mutagenic and teratogenic in laboratory animals [38, 39]. The search for antiparasitic agents in marine organisms is extensive, however, there are few reports about the effects of venoms from sea anemones and jellyfish against bacteria and parasites $[40,41]$. The antigiardial in vitro assays of several cnidarian extracts show good activity of the jellyfish Linuche unguiculata $\left(\mathrm{IC}_{50}\right.$ of 63 . $2 \mu \mathrm{g} / \mathrm{mL}$ ) and poor activity of the sea anemone Stichodactyla helianthus $\left(\mathrm{IC}_{50}\right.$ of $1388 \mu \mathrm{g} / \mathrm{mL}$ ) [16]. Nevertheless, the antigiardial activity was improved when the extract was replaced by a compound obtained from cnidaria [42].

The components responsible for this kind of activity have not been isolated, but according to the morphological changes and final lysis observed in our experiments, we could hypothesize that the molecules involved in this antigiardial effect could be cytolysins and/or phospholipases. The best known cnidarian cytolysins are actinoporins, cytolitic proteins that permeate cell membranes by forming transmembrane pores and causing cell lysis [43]. Although no actinoporin has been isolated from zoanthids, their presence has been well stablished within sea anemones.

P. caribaeorum contains phospholipases with potential membrane lysis activity. Actually, a $16 \mathrm{kDa}$ phospholipase $\mathrm{A}_{2}$ has been isolated from P. caribaeorum but its mechanism of action is still to be elucidated. Finally, another potential mechanism, although not observed within the present study, could be the presence of molecules that elicit morphological changes via the damage of trophozoites cytoskeleton by albendazole or curcumin [44].

Cytotoxins isolated from different venom sources have shown various physiological effects, such as modulation of the activity of membrane enzymes, depolarization of excitable membranes, inhibition of platelet aggregation, cardiac arrest, hemolysis and cytotoxicity [33]. The experiments carried out in this study showed the presence of cytotoxins in P. caribaeorum extract. These toxins, although not chemically described here, must be of proteinacious nature. Such hypothesis is based on previously reported mass spectrometry analysis and by the loss of the enzymatic activity after incubation of the extract with boiling water [30]. However, we cannot discard the presence of anticancer terpenoids, since they are abundant and have been isolated in all classes within phylum Cnidaria [6].

\section{Conclusions}

In summary, the present results show that $P$. caribaeorum contains substances with a broad variety of pharmacological activities, which makes the order Zoantharia - including sea anemones and jellyfishes - a viable option in the search for novel molecules. Further research is necessary to identify the molecules that exert these activities and to determine whether the venom contains useful compounds suitable for other pharmaceutical purposes.

\section{Abbreviations \\ $\mathrm{EC}_{50}$ : Half-maximal effective concentration; $\mathrm{LD}_{50}$ : Lethal dose 50 ; $\mathrm{NCl}$ : National Cancer Institute; PLA $\mathrm{A}_{2}$ : Phospholipase $\mathrm{A}_{2}$}

\section{Acknowledgments \\ The authors wish to thank Ricardo González-Muñoz for identification of the organism species and Hortensia Segura Silva for graphical design. F. L-P acknowl- edges the post-graduate program from Ciencias del Mar y Limnología, UNAM.}

\section{Funding}

This work was financially supported by grants from PAPIIT IN202614, IG 200218 and Consejo Nacional de Ciencia y Tecnología (CONACyT) scholarship 202738.

\section{Authors' contributions}

FLP, AZM and MCC performed collection of samples and venom extraction. AGA performed the aorta, insect toxicity and hemolytic experiments. YRG and MPM, performed antiparasitic experiment. All authors contributed with the bioassays. All authors read and approved the final manuscript.

\section{Ethics approval}

The animal utilization was approved by the Committee of Bioethics of the School of Medicine, UAQ. Specimen collection was conducted according to the guidelines of the National Commission of Aquaculture, Fishing, and Feeding of the Mexican Federal Government (permit number PPF/DGOPA-193/13).

Consent for publication

Not applicable.

\section{Competing interests}

The authors declare that they have no competing interests.

\section{Publisher's Note}

Springer Nature remains neutral with regard to jurisdictional claims in published maps and institutional affiliations.

\section{Author details}

'Departamento de Química de Biomacromoléculas, Instituto de Química, Universidad Nacional Autónoma de México, Av. Universidad 3000, Ciudad Universitaria, C.P. 04510. Apdo, Postal 70250 Mexico City, Mexico. ${ }^{2}$ Laboratorio de Parasitología Experimental, Instituto Nacional de Pediatría, Insurgentes Sur 3700-C, 04530 Mexico City, Mexico. ${ }^{3}$ Laboratorio de Investigación Química y Farmacológica de Productos Naturales, Facultad de Química, Universidad Autónoma de Querétaro, Centro Universitario, 76010 Querétaro, Mexico. ${ }^{4}$ CONACYT-Instituto Nacional de Pediatría, Secretaría de Salud, 04530 Mexico City, Mexico. ${ }^{5}$ Laboratorio de Bioquímica Genética, Instituto Nacional de Pediatría, Insurgentes Sur 3700-C, 04530 Mexico City, Mexico.

Received: 1 December 2017 Accepted: 27 March 2018 Published online: 17 April 2018

\section{References}

1. Collins AG. Recent insights into Cnidarian phylogeny. Smithson Contrib Mar Sci. 2009;38:139-49.

2. Turk T, Kem WR. The phylum Cnidaria and investigations of its toxins and venoms until 1990. Toxicon. 2009;54(8):1031-7. 
3. Burnett JW, Weinrich D, Williamson JA, Fenner PJ, Lutz LL, Bloom DA. Autonomic neurotoxicity of jellyfish and marine animal venoms. Clin Auton Res. 1998;8(2):125-30.

4. Beress L. Biologically active compounds from coelenterates. Pure Appl Chem. 1982;54(10):1981-94.

5. Jouiaei M, Yanagihara AA, Madio B, Nevalainen T, Alewood PF, Fry BG. Ancient venom systems: a review on Cnidaria toxins. Toxins (Basel). 2015; 7(6):2251-71.

6. Mariottini GL, Pane L. Cytotoxic and Cytolytic cnidarian venoms. A review on health implications and possible therapeutic applications. Toxins (Basel). 2014;6(1):108-51.

7. Edwards LP, Whitter E, Hessinger DA. Apparent membrane pore-formation by Portuguese man-of-war (Physalia physalis) venom in intact cultured cells. Toxicon. 2002;40(9):1299-305.

8. Tibballs J. Australian venomous jellyfish, envenomation syndromes, toxins and therapy. Toxicon. 2006;48(7):830-59.

9. Mariottini GL, Sottofattori E, Mazzei M, Robbiano L, Carli A. Cytotoxicity of the venom of Pelagia noctiluca forskal (Cnidaria: Scyphozoa). Toxicon. 2002; 40(6):695-8.

10. Marino A, Crupi R, Rizzo G, Morabito R, Musci G, La Spada G. The unusual toxicity and stability properties of crude venom from isolated nematocysts of Pelagia noctiluca (Cnidaria, Scyphozoa). Cell Mol Biol (Noisy-le-grand). 2007:53(Suppl):994-1002.

11. García-Arredondo A, Rojas-Molina A, Ibarra-Alvarado C, Iglesias-Prieto R. Effects of bleaching on the pharmacological and toxicological activities elicited by the aqueous extracts prepared from two "fire corals" collected in the Mexican Caribbean. J Exp Mar Bio Ecol. 2011;396(2):171-6.

12. García-Arredondo A, Murillo-Esquivel LJ, Rojas A, Sanchez-Rodriguez J. Characteristics of hemolytic activity induced by the aqueous extract of the Mexican fire coral Millepora complanata. J Venom Anim Toxins incl Trop Dis. 2014;20:49. https://doi.org/10.1186/1678-9199-20-49.

13. Santamaría A, Sánchez-Rodríquez J, Zugasti A, Martínez A, Galván-Arzate S, Segura-Puertas L. A venom extract from the sea anemone Bartholomea annulata produces haemolysis and lipid peroxidation in mouse erythrocytes. Toxicology. 2002;173(3):221-8.

14. Monroy-Estrada HI, Segura-Puertas L, Galván-Arzate S, Santamaría A, Sánchez-Rodríguez J. The crude venom from the sea anemone Stichodactyla helianthus induces haemolysis and slight peroxidative damage in rat and human erythrocytes. Toxicol in Vitro. 2007;21(3):398-402.

15. Suput D. In vivo effects of cnidarian toxins and venoms. Toxicon. 2009;54(8): 1190-200.

16. Morales-Landa JL, Zapata-Pérez O, Cedillo-Rivera R, Segura-Puertas L, SimáAlvarez R, Sanchez-Rodriguez J. Antimicrobial, antiprotozoal, and toxic activities of cnidarian extracts from the Mexican Caribbean Sea. Pharm Biol. 2007:45(1):37-43.

17. Ovchinnikova TV, Balandin SV, Aleshina GM, Tagaev AA, Leonova YF, Krasnodembsky ED, et al. Aurelin, a novel antimicrobial peptide from jellyfish Aurelia aurita with structural features of defensins and channelblocking toxins. Biochem Biophys Res Commun. 2006:348(2):514-23.

18. Gleibs S, Mebs D. Distribution and sequestration of palytoxin in coral reef animals. Toxicon. 1999:37(11):1521-7.

19. Usami M, Satake M, Ishida S, Inoue A, Kan Y, Yasumoto T. Palytoxin analogs from the dinoflagellate Ostreopsis siamensis. J Am Chem Soc. 1996;117(19): 5389-90.

20. López-Abarrategui C, Alba A, Lima LA, Maria-Neto S, Vasconcelos IM, Oliveira JTA, et al. Screening of antimicrobials from Caribbean Sea animals and isolation of bactericidal proteins from the littoral mollusk Cenchritis muricatus. Curr Microbiol. 2012;64(5):501-5.

21. Alencar DB, Melo AA, Silva GC, Lima RL, Pires-Cavalcante KMS, Carneiro RF, et al. Antioxidant, hemolytic, antimicrobial, and cytotoxic activities of the tropical Atlantic marine zoanthid Palythoa caribaeorum. An Acad Bras Cienc. 2015:87(2):1113-23.

22. Lazcano-Pérez F, Vivas O, Román-González SA, Rodríguez-Bustamante E, Castro $\mathrm{H}$, Arenas I, et al. A purified Palythoa venom fraction delays sodium current inactivation in sympathetic neurons. Toxicon. 2014;82:112-6.

23. Rottini G, Gusmani L, Parovel E, Avian M, Patriarca P. Purification and properteis of a cytolytic toxin in venom of the jellyfish Carybdea marsupialis. Toxicon. 1995;33(3):315-26.

24. Herzig V, Khalife AA, Chong Y, Isbister GK, Currie BJ, Churchill TB, et al. Intersexual variations in northern (Missulena pruinosa) and eastern (M. bradleyi) mouse spider venom. Toxicon. 2008;51(7):1167-77.
25. Monks A, Scudiero D, Skehan P, Shoemaker R, Paull K, Vistica D, et al. Feasibility of a high-flux anticancer drug screen using a diverse panel of cultured human tumor cell lines. J Natl Cancer Inst. 1991;83(11):757-66.

26. Valcarcel CA, Dalla Serra M, Potrich C, Bernhart I, Tejuca M, Martinez D, et al. Effects of lipid composition on membrane permeabilization by sticholysin I and II, two cytolysins of the sea anemone Stichodactyla helianthus. Biophys 2001;80(6):2761-74.

27. Bosmans F, Tytgat J. Sea anemone venom as a source of insecticidal peptides acting on voltage-gated Na+ channels. Toxicon. 2007:49(4):550-60.

28. Billen B, Debaveye S, Béress L, Garateix A, Tytgat J. Phyla- and subtypeselectivity of $\mathrm{CgNa}$, a $\mathrm{Na}+$ channel toxin from the venom of the Giant Caribbean Sea Anemone Condylactis gigantea. Front Pharmacol. 2010;1:133.

29. García-Arredondo A, Rojas-Molina A, Ibarra-Alvarado C, Lazcano-Pérez F, Arreguín-Espinosa R, Sánchez-Rodríguez J. Composition and biological activities of the aqueous extracts of three scleractinian corals from the Mexican Caribbean: Pseudodiploria strigosa, Porites astreoides and Siderastrea siderea, J Venom Anim Toxins incl Trop Dis 2016;22:32. doi: https://doi.org/ 10.1186/s40409-016-0087-2.

30. Lazcano-Pérez F, Castro H, Arenas I, García DE, González-Muñoz R, ArreguínEspinosa R. Activity of Palythoa caribaeorum venom on voltage-gated ion channels in mammalian superior cervical ganglion neurons. Toxins (Basel). 2016:8(5):135

31. García-Arredondo A, Rojas-Molina A, Bah M, Ibarra-Alvarado C, GallegosCorona MA, García-Servín M. Systemic toxic effects induced by the aqueous extract of the fire coral Millepora complanata and partial purification of thermostable neurotoxins with lethal effects in mice. Comp Biochem Physiol C Toxicol Pharmacol. 2015;169:55-64.

32. Ibarra-Alvarado C, Alejandro García J, Aguilar MB, Rojas A, Falcón A. Heimer de la Cotera EP. Biochemical and pharmacological characterization of toxins obtained from the fire coral Millepora complanata. Comp Biochem Physiol C Toxicol Pharmacol. 2007:146(4):511-8.

33. Gomes A, Bhattacharjee P, Mishra R, Biswas AK, Dasgupta SC, Giri B. Anticancer potential of animal venoms and toxins. Indian J Exp Biol. 2010; 48(2):93-103.

34. Carli A, Bussotti S, Mariottini GL, Robbiano L. Toxicity of jellyfish and seaanemone venoms on cultured V79 cells. Toxicon. 1996;34(4):496-500.

35. Marino A, Valveri V, Muià C, Crupi R, Rizzo G, Musci G, et al. Cytotoxicity of the nematocyst venom from the sea anemone Aiptasia mutabilis. Comp Biochem Physiol C Toxicol Pharmacol. 2004;139(4):295-301.

36. Monroy-Estrada HI, Chirino YI, Soria-Mercado IE, Sanchez-Rodriguez J. Toxins from the Caribbean Sea anemone Bunodeopsis globulifera increase cisplatininduced cytotoxicity of lung adenocarcinoma cells. J Venom Anim Toxins incl Trop Dis. 2013;19(1):12. https://doi.org/10.1186/1678-9199-19-12.

37. Alizadeh A, Ranjbar M, Kashani KM, Taheri MM, Bodaghi M. Albendazole versus metronidazole in the treatment of patients with giardiasis in the Islamic Republic of Iran. East Mediterr Health J. 2006:12(5):548-54.

38. Cañete R, Rodríguez P, Mesa L, Brito K, Prior A, Guilhem D, et al. Albendazole versus metronidazole in the treatment of adult giardiasis: a randomized, double-blind, clinical trial. Curr Med Res Opin. 2012;28(1):149-54.

39. Bendesky A, Menéndez D, Ostrosky-Wegman P. Is metronidazole carcinogenic? Mutat Res. 2002;511(2):133-44.

40. Bianco EM, de Oliveira SQ, Rigotto C, Tonini ML, da Rosa GT, Bittencourt F, et al. Anti-infective potential of marine invertebrates and seaweeds from the Brazilian coast. Molecules. 2013;18(5):5761-78.

41. Thao NP, Luyen BT, Brun R, Kaiser M, Van Kiem P, Van Minh C, et al. Antiprotozoal activities of cembrane-type diterpenes from Vietnamese soft corals. Molecules. 2015;20(7):12459-68.

42. Tejuca M, Anderluh G, Macek P, Marcet R, Torres D, Sarracent J, et al Antiparasite activity of sea-anemone cytolysins on Giardia duodenalis and specific targeting with anti-Giardia antibodies. Int J Parasitol. 1999;29(3):489-98.

43. Kristan KC, Viero G, Dalla Serra M, Macek P, Anderluh G. Molecular mechanism of pore formation by actinoporins. Toxicon. 2009;54(8):1125-34.

44. Pérez-Arriaga L, Mendoza-Magaña ML, Cortés-Zárate R, Corona-Rivera A Bobadilla-Morales L, Troyo-Sanromán R, et al. Cytotoxic effect of curcumin on Giardia lamblia trophozoites. Acta Trop. 2006:98(2):152-61. 